\title{
VÝZNAM VALOUNOVÝCH ANALÝZ LEDOVCOVÝCH SEDIMENTŮ PRO PALEOGEOGRAFICKÉ REKONSTRUKCE PLEISTOCENNÍHO KONTINENTÁLNIIHO ZALEDNĚNÍ JESENICKA
}

\author{
Importance of clast petrological analyses of glacial sediments for palaeogeographical \\ reconstruction of Pleistocene continental glaciation in the Jeseníky area
}

\author{
Martin Hanáček \\ Ústav geologických věd PřF MU, Kotlářská 2, 61137 Brno; e-mail: HanacekM@seznam.cz \\ Centrum polární ekologie, Jihočeská univerzita v Českých Budějovicích, Na Zlaté Stoce 3, 37005 České Budějovice
}

(04-44 Javorník, 14-22 Jeseník)

Key words: clast petrology and provenance, continental glaciation sediments, advance directions of continental glacier, Pleistocene, Rychleby Mts. foothill, Zlaté Hory Highlands

\begin{abstract}
Sediments of Middle Pleistocene continental glaciation at the northern foothill of Rychleby Mts. and Zlaté Hory Highland contain clasts of local to Nordic provenance. Local clasts originating from crystalline units of the above-mentioned mountains prevail. These clasts have palaeogeographical importance for a local reconstruction of ice sheet advance directions. General advance direction from NW to SE has been reconstructed basing on local clasts in earlier studies (mainly Gába 1981a, b; Gába - Pek 1999). This interpretation has been based on the fact that the shares of clasts of rocks cropping primarily in NW part of the Rychleby Mts. decrease towards the SE. New, in this contribution presented, interpretation reconstructs the ice sheet advance generally from the North to the South, with variations conditioned by local landscape. Glacial sediments have at each site in the NW-SE direction petrological composition, which corresponds to the lithology of a mountain part south of the site of concern. Gierattow orthogneiss clasts predominate in glacial deposits of the NW part of the main ridge forefield of Rychleby Mts. The share of amphibolites rises significantly in the forefield of the central part of the Rychleby Mts. main ridge. Feldspar and muscovite quartzites dominate in the area of Sokol Ridge and Zlaté Hory Highlands. The new interpretation presumes the colluvial, alluvial and fluvial transport of the debris towards the northern and north-eastern mountain forefield before the ice sheet advance. Ice sheet advancing from the North eroded and transported this debris towards the South. Preglacial sediments corresponded petrologically to the mountain parts, from which they originated. Thus, glacial sediments have petrological composition, which corresponds to the lithology of those mountain parts, which lies south of the sediment occurrence. Part of the debris has been transported by Nisa Kłodzka River from the West towards the East already before the glaciation.

The following pattern could be found in the petrological composition of the glacial sediments gravel fraction. Sediments with monotonous composition of local clasts contain low shares of Nordic and Poland clasts ( 2-4\%). On the contrary, sediments with polymict composition of local clasts contain relatively high shares of Nordic and Poland clasts (up to $27 \%$ ). Monotonous and distant provenance poor sediments originated at places, where the source preglacial deposits must have been petrologically monotonous considering the lithology of source areas. Concurrently, morphologically conditioned preglacial accumulation of vast lithologically monotonous deposits took place at some places (proximal parts of mountain ridges and saddles foothill). Rather polymict and distant provenance clast rich sediments originated during the later phase of ice sheet decay. Debris from the whole ice sheet body, not only from the glacier base or its front, released to the depositional system at that time. Sites with these sediments are located beyond the mountain foothill, where mixing of debris originating from alluvial fans or rivers flowing form the mountain range took place. Petrologically by far more monotonous sediments have been deposited closer to the mountain foothill.

Quartz clasts are mostly of local origin and have together with other clasts been part of preglacial sediments. Part of quartz clasts has been reworked from fluvial deposits of present Poland or they might originate from the Nordic areas.
\end{abstract}

Úvod

Ledovcové sedimenty jesenického regionu, tj. v severním předpolí Rychlebských hor a ve Zlatohorské vrchovině, jsou reprezentovány tilly a dále glacifluviálními a glacilakustrinními uloženinami (Cháb et al. 2004; Žáček et al. 2004). Stratigraficky jsou v poslední době kladeny do elsterského zalednění (Nývlt et al. 2011). Materiálové složení štěrkové frakce těchto sedimentů se vyznačuje převahou hornin místní provenience (metamorfity orlicko-sněžnického krystalinika, staroměstského krystalinika, silezika a variské granitoidy). Horniny z nordické oblasti (granitoidy, vulkanity, metamorfity a pískovce baltského štítu a sedimentární horniny jeho paleozoicko-kenozoické platformy) jsou zastoupeny podstatně vzácněji. Původem polské horniny (sudetské porfyry, silicity, pískovce) mají akcesorické podíly. Nejednoznačnou, i když většinou místní provenienci, mají klasty křemene, které se také podstatnou měrou podílejí na skladbě štěrkového materiálu těchto sedimentů. Poněkud nejasného původu je bazalt, který může pocházet $\mathrm{z}$ různých výchozů $\mathrm{v}$ Polsku a z malé části z Rychlebských hor a z nordické oblasti.

Petrografickým studiem štěrkové frakce ledovcových sedimentů Jesenicka se zabývají studie citované dále. Z nich nevýznamnější je monografická práce Gáby-Peka (1999). Písčitou frakci a strukturní znaky sedimentů studovali zejména Kopečný - Pek (1974) a Sikorová et al. (2006). Štěrkové klasty místních hornin byly využity k řešení paleogeografie zalednění studované oblasti (mj. Gába 1981a, b), což je také hlavním předmětem zájmu tohoto př́spěvku. 


\section{Metodika}

Vzorky pro valounové analýzy byly odebrány ze začištěných profilů pomocí lopatky a normalizovaného síta. Použitá frakce $16-64 \mathrm{~mm}$ v b-ose zajištuje dobrou petrografickou určitelnost klastů a je dostatečně reprezentativní pro studované sedimenty. Místní klasty byly přiřazovány ke konkrétním horninovým typům, klasty nordického a polského původu jsou zahrnuty do jedné provenienční skupiny. Křemenné a bazaltové klasty jsou poznatelné petrograficky, ale ne $\mathrm{z}$ hlediska původu. Do kategorie ostatních a neurčitelných hornin spadají petrograficky bliže neidentifikované, byt' nejpravděpodobněji místní horniny, a provenienčně ani petrograficky neurčené horniny. Klasty s nerozpoznaným horninovým typem a původem představují jen první \% materiálu. Determinace hornin probíhala většinou makroskopicky, pouze u některých typů mikroskopicky na výbrusech.

Přesnější původ místních klastů byl řešen pomocí geologických map studované oblasti a jejich vysvětlivek (Svoboda et al. 1961; Pouba et al. 1962; Svoboda 1990; Skácelová 1993, 1994; Sawicki 1995; Žáček 1995; Pouba 1996; Cháb et al. 2004; Žáček et al. 2004; Pecina et al. 2005). Dále byla využita práce Gáby - Peka (1999). Podle těchto map byly nakresleny i mapky na obrázku 1 .

Valounové analýzy prezentované $\mathrm{v}$ tomto př́spěvku většinou vycházejí $\mathrm{z}$ dř́ivějších studií autora (Hanáček 2008, 2011, 2012; Hanáček et al. 2013a, b). Dílčí analýzy z geneticky a stratigraficky stejných sedimentů či faciálních asociací na každé lokalitě byly pro tuto studii zprůměrovány. Počet zprůměrovaných analýz frakce 16-64 mm a celkový počet klastů $\mathrm{v}$ nich obsažených jsou následující: Písečník (subglaciální sekvence) - 2 analýzy, 1141 klastů; Písečník (supraglaciální sekvence) - 2 analýzy, 1093 klastů; Stachlovice - 2 analýzy, 1185 klastů; Stará kaolínová jáma - 3 analýzy, 3022 klastů; Kolnovice (vzorky SG1a-SG1f) - 6 analýz, 3791 klastů; Kolnovice (vzorky G1a-G1e) - 5 analýz, 3042 klastů; Kolnovice (vzorky G1f a G1g) - 2 analýzy, 1133 klastů; Kolnovice (vzorky SG2a-G2b) - 4 analýzy, 2463 klastů; Javorná - 2 analýzy, 1154 klastů. Průměrné počty klastů se tedy pohybují mezi 547 a 695, pouze na lokalitě Stará kaolínová jáma činí 1 007. Z lokalit Polský kopec a Písečná byla kvůli špatné odkrytosti vyhodnocena $\mathrm{v}$ obou př́padech jen 1 analýza s 695, respektive 679 klasty. Polohu lokalit, výsledky valounových analýz i vztah společenstev klastů ke geologii skalního podloží ukazuje obrázek 1 .

\section{Charakteristika lokalit \\ Písečník}

Jedná se ploché návrší $0,6 \mathrm{~km}$ severně od Javorníku budované miocenními písky, překrytými subglaciálními a supraglaciálními tilly a glacifluviálními sedimenty. Písečník je interpretován jako drumlin tvořený podložními horninami a na nich ležícími tilly.

Pro ledovcové sedimenty Písečníku je typická hojnost klastů bělošedé až načervenalé dvojslídné ruly, odpovídající gierałtowské ortorule. Tvoří 73\% klastů subglaciálních sedimentů a $\sim 33 \%$ klastů supraglaciál- ních sedimentů. Kvarcity, amfibolit, svor, bazalt a světlé granitoidy jsou zastoupeny v desetinách \% až prvních \%. Grafitický kvarcit a bazalt jsou na Písečníku v porovnání $s$ východněji ležícími lokalitami zdaleka nejpočetnější. Subglaciální sedimenty jsou velmi chudé na nordické a polské horniny $(\sim 2,5 \%)$ a křemen $(\sim 9 \%)$, zatímco supraglaciální sedimenty jich obsahují více $(\sim 12 \%$ nordik a $\sim 19 \%$ křemene). Velmi vzácně se objevuje granulit provenienčně spjatý s gierałtowskou ortorulou.

\section{Stachlovice}

Lokalitou je malá zaniklá pískovna ležící $0,2 \mathrm{~km} \mathrm{sz}$. od osady Stachlovice na Vidnavsku. Nachází se přímo na horní hraně svahu, kterým je severní okraj Žulovské pahorkatiny omezen proti údolí řeky Vidnávky (Vidnavské nížině). Lokalita odkrývá kontakt členitého paleoreliéfu žulovského masivu s elevacemi a depresemi, které jsou vyplněny faciálně pestrými ledovcovými uloženinami (štěrky, písky a diamiktony). Sedimenty jsou interpretovány jako glacitektonity, melt-out tilly a glacifluviální sedimenty deponované v subglaciální pozici.

Stachlovice jsou jedinou lokalitou s dominancí amfibolitu ve štěrkovém materiálu ( 25\%). Následuje bělošedá až načervenalá dvojslídná ortorula gierałtowského typu ( 18 \%), další horniny sudetského krystalinika jsou zastoupeny v desetinách \% až v prvních \%. Zajímavý je podíl klastů šedých granitoidů ( 3,5\%), jenž lze považovat za velmi nízký, vzhledem k pozici ledovcových sedimentů prrímo na žulovském masivu a k prítomnosti velkých ostrohranných bloků granitoidů masivu v diamiktonech na lokalitě. Podíl nordických a polských hornin dosahuje $\sim 10 \%$, podíl křemenných klastů 23\%.

\section{Stará kaolínová jáma a Polský kopec}

Obě lokality jsou součástí stejné glacifluviální akumulace jv. od Vidnavy. Ve Staré kaolínové jámě se jedná o sedimenty odkryté těžbou v nadloží kaolínu, druhou lokalitu představuje zaniklá pískovna za vidnavskou skládkou, ve svahu pohraničního návrší neformálně nazývaného jako „Polský kopec“. Na obou lokalitách převládají šikmo korytovitě a planárně zvrstvené štěrkovité písky a písky, šedé až šedohnědé barvy. Podřízeně jsou přítomny polohy štěrků. V sedimentech je pozorovatelný nahoru zjemňující trend od štěrků do písků. V závěru vrstevního sledu jsou na obou lokalitách vyvinuty horizonty glacilakustrinních písků a siltů (Gába 1992). Nejpravděpodobněji se jedná o sedimenty terminoglaciální až proglaciální výplavové plošiny.

Lokality jsou si velmi podobné i petrograficky. Ve štěrkovém materiálu převládá gierałtowská ortorula ( 20-21\%), doprovázená zcela ojedinělými klasty granulitu. Podíly amfibolitů kolísají mezi $4,5 \%$ ve Staré kaolínové jámě a $11 \%$ na Polském kopci. Šedé granitoidy žulovského masivu jsou stejně jako v sousedních Stachlovicích spíše vzácné ( 3,5-4,5\%). Pro Starou kaolínovou jámu i Polský kopec je charakteristický vysoký podíl klastů nordických a polských hornin pohybující se mezi 23 a $27 \%$. Zastoupení křemene dosahuje 18-21\%. 


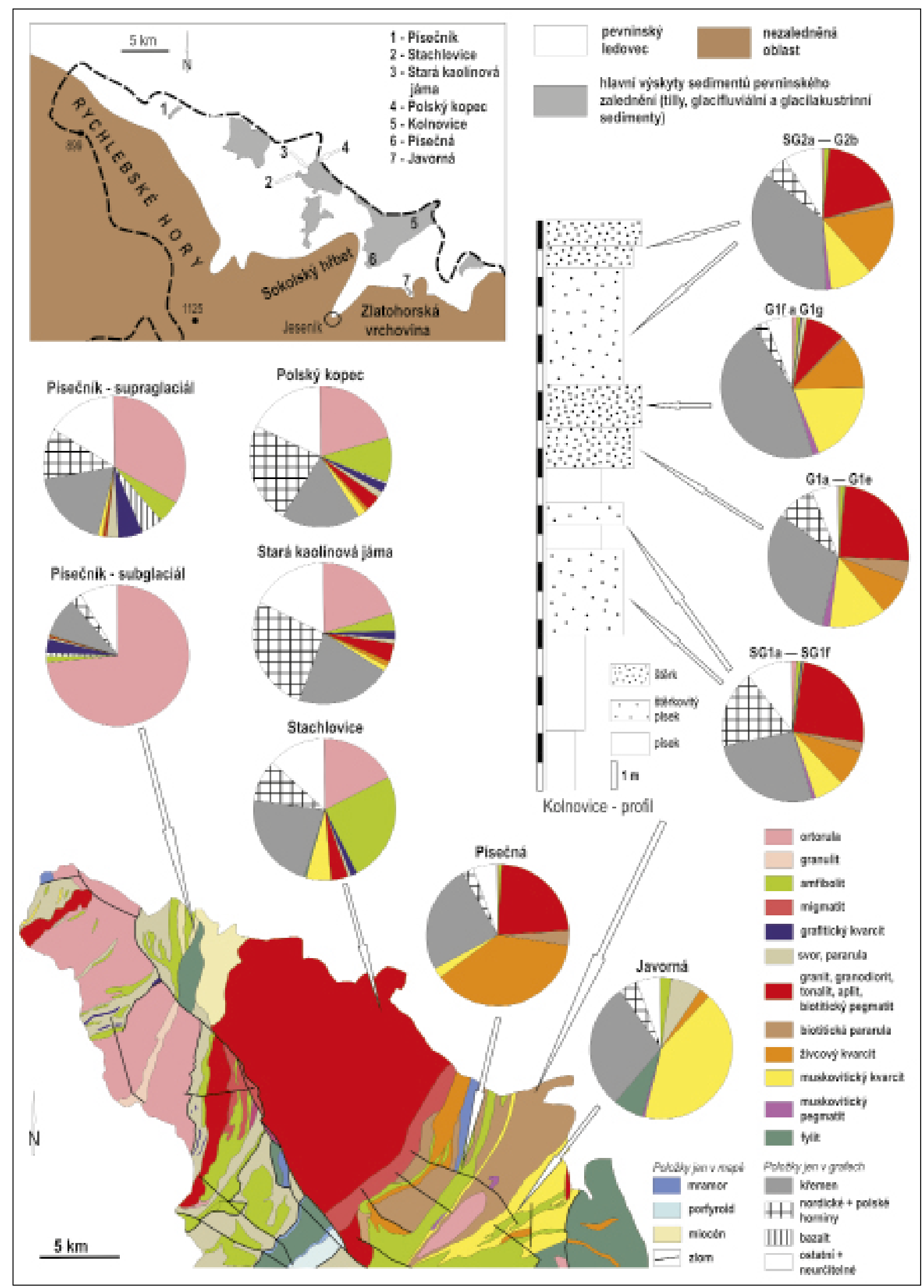

Obr. 1: Poloha lokalit, grafy valounových analýz, schematický profil lokalitou Kolnovice, geologická mapa předkvartérních jednotek. Fig. 1: Localities positions, clast petrology diagrams, sketch section of the Kolnovice locality, geological map of pre-Quartenary units in studied area. 


\section{Kolnovice}

Jedná se o rozlehlou aktivní pískovnu nacházející se $1,5 \mathrm{~km}$ severozápadně od Mikulovic, $\mathrm{v}$ místě přechodu horského údolí mezi Sokolským hřbetem a Zlatohorskou vrchovinou do otevřeného plochého předpolí Sudet. $\mathrm{V}$ přibližně $20 \mathrm{~m}$ mocném profilu převládají šikmo planárně a šikmo korytovitě zvrstvené štěrkovité písky a písky s podřízenými polohami masivních štěrků (obr. 1). Akumulace nejspíš představuje proglaciální glacifluviální výplavovou plošinu.

Štěrkový materiál se směrem do nadloží vyvíjí $\mathrm{v}$ tomto trendu (obr. 1). Pro spodní část profilu (zprůměrovaná analýza ze vzorků SG1a-SG1f, viz Hanáček 2012) jsou typické vysoké podíly šedých granitoidů žulovského masivu ( 25\% ) a nordických a polských hornin ( 18\%). Klasty živcového „pórovitého“ kvarcitu představují 8\% a muskovitického kvarcitu 7\%. Podíl křemene činí 26\%. Ve střední části (G1a-G1e) se složení klastů laterálně značně mění, přičemž šedé granitoidy zůstávají převažující komponentou mezi horninovými klasty ( 24 \%). Podíl nordik klesá na $\sim 9 \%$, zastoupení živcového „pórovitého“ kvarcitu zůstává stejné, zatímco muskovitický kvarcit narůstá na $\sim 13 \%$. Křemenné klasty představují 31 \% štěrku. Ve zhruba $2 \mathrm{~m}$ mocné akumulaci hrubého štěrku (G1g a G1f) ve střední části sledu výrazně dominuje křemen ( 46 \%), z hornin pak muskovitický kvarcit ( 19\%) a živcový „pórovitý“ kvarcit ( 12\%). Podíl šedých granitoidů klesá na $\sim 9 \%$ a nordických a polských hornin na $\sim 2,5 \%$. Svrchní část profilu (SG2a-G2b) se vyznačuje opět značnou převahou křemene $(\sim 36 \%)$ nad horninovými klasty šedých granitoidů ( 20\%), živcového „pórovitého“ kvarcitu $(\sim 16 \%)$ a muskovitického kvarcitu ( 10\%). Podíl nordik se pohybuje v prvních \%. Pro celou akumulaci je charakteristická akcesorická př́tomnost klastů muskovitického pegmatitu a granitu $(\sim 1 \%)$.

\section{Písečná}

Lokalitu představuje velká nečinná pískovna při severním okraji obce Písečná, na východním úpatí Sokolského hřbetu. Těžbou je odkryt až 45 m mocný vrstevní sled převážně glacifluviálních písků, štěrkovitých písků a štěrků, přičemž mocná poloha hrubozrnného štěrku je vázána na svrchní část profilu v severním úseku pískovny. Jedná se pravděpodobně o terminoglaciální kužel nebo hrubozrnnou deltu situovanou v boční straně údolí řeky Bělé.

Ačkoliv při vlastním výzkumu byla vyhodnocena jen jedna analýza $z$ hrubých štěrků ve svrchní části profilu (obr. 1), další analýzy zpracoval již dřive Gába (1981a, b). Mocná akumulace se podle těchto výsledků jeví petrograficky uniformní a málo polymiktní Dominuje živcový „pórovitý“ kvarcit, tvořící 40-50 \% štěrkových klastů. Zhruba 16-29\% klastů tvoří šedé granitoidy, provenienčně vztahované k žulovskému masivu. Nordika jsou vzácná ( 2-4\%), podíl křemene kolísá mezi 15 a $45 \%$.

\section{Javorná}

Lokalitou je malá zaniklá pískovna ve Zlatohorské vrchovině, jižně od sedla mezi vrcholy Bílým kamenem
(613 m n. m.) a Strážiskem (610 m n. m.). Odkryté sedimenty jsou součástí nevelké akumulace glacifluviálních uloženin, která navazuje na subglaciální tilly zjištěné v uvedeném sedle. Jedná se o nejvýše položený dosud známý výskyt ledovcových sedimentů v České republice (Gába 1972a; Prosová 1981; Cháb et al. 2004). Glacifluviální akumulace se pravděpodobně vyvíjela jako štěrkovito-písčitý terminoglaciální kužel, progradující boční stranou údolí říčky Javorné od ledovce, spočívajícího v uvedeném sedle a v jeho severním zápolí.

Petrograficky převažuje muskovitický kvarcit ( 41\% klastů). Relativně vysoké podíly svoru a fylitu (každá z obou hornin $\sim 7 \%$ ) souvisejí se svorovými a fylitovými vložkami ve zdrojových souvrstvích muskovitických kvarcitů vrbenské skupiny. Muskovitické pegmatity $\mathrm{z}$ údolí Bělé představují desetiny \% klastů, šedé granitoidy vztažitelné k žulovskému masivu pak setiny \%. Podíl nordických klastů je nízký ( 4 \%), podíl křemene dosahuje 30\%.

\section{Interpretace a diskuze \\ Význam provenienčně místních klastů pro rekonstrukci směru postupu ledovce}

Petrografické složení klastů místního původu je v ledovcových sedimentech značně variabilní, i když pokaždé odpovídá litologii sousedních geologických jednotek (Gába 1974, 1976; Nývlt - Hoare 2000; Sedláček 2008; Hanáček - Nývlt 2009; Šimíček 2009; Štor 2009; Černá et al. 2012). Na Jesenicku vymezili Gába (1977) a Gába - Pek (1999) některé makroskopicky dobře poznatelné místní horniny, obsažené v ledovcových uloženinách, jako tzv. lokální vůdčí souvky a $\mathrm{z}$ jejich četnosti $\mathrm{v}$ sedimentech vyvozovali závěry o směru postupu pevninského ledovce na severním předpolí Rychlebských hor a Zlatohorské vrchoviny. Jelikož podíly klastů pocházejících z hlavního hřebene Rychlebských hor klesaly ve směru SZ-JV, stanovili shodně i směr šíření ledovce. Směr SZ-JV souhlasil s orientací širokého údolí Odry v jižním Polsku, kudy se měl ledovec generelně šírit (Gába 1976). Úbytek klastů sledovaných hornin $\mathrm{v}$ sedimentech ve směru postupu ledovce byl vysvětlován zřed’ovacím efektem způsobeným novým materiálem zakomponovaným do subglaciální zóny během pohybu ledovce, dále pak rozpadem a ukládáním těchto klastů (Gába - Pek 1999). Instruktivním příkladem klesajícího trendu v zastoupení klastů z hlavního hřebene Rychlebských hor je četnost grafitického kvarcitu, jenž $\mathrm{v}$ ledovcových sedimentech Javornicka představuje max. $14 \%$, na Vidnavsku a Žulovsku první \% a na v. straně Sokolského hřbetu již jen desetiny procenta štěrkového materiálu ledovcových sedimentů (Gába - Pek 1999). Podobný trend zjistili Gába - Wójcik (1990) u klastů sudetského porfyru v rámci jižního Polska a severní Moravy. Petrografické složení i orientace klastů v tillu u Skorošic na Žulovsku rovněž jasně ukazuje na postup ledovce od SZ na JV, tj. podél severovýchodního úpatí hlavního hřebene Rychlebských hor (Gába 1972b). Podle petrografické skladby štěrkového materiálu lokality Písečná rekonstruoval Gába (1981a, b) směr šíření zalednění následovně: ledovec postupoval podél úpatí hlavního hřebene Rychlebských hor na JV, pak se stáčel podél Sokolského hřbetu na V-SV 


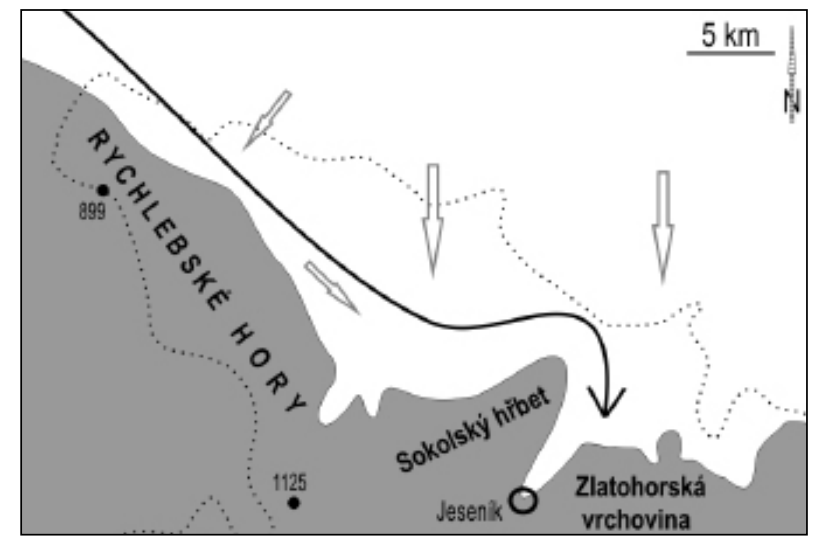

Obr. 2: Bíle: zaledněná oblast, šedě: nezaledněná oblast. Černá šipka: směr postupu pevninského ledovce podle Gáby (1981). Bílé šipky: směr postupu ledovce podle tohoto článku.

Fig. 2: White: glaciated area. Grey: non-glaciated area. Black arrow: advance direction of continental glacier after Gába (1981). White arrows: advance directions of continental glacier interpreted in this study.

a poté, již na východní straně Sokolského hřbetu, se stočil na J a postupoval k Písečné (obr. 2).

Till u Skorošic obsahuje 19\% klastů xylitu, který má primární výchozy v Uhelné, sz. od skorošické lokality, a rovněž většina protáhlých klastů v tomto tillu je orientována ve směru SZ-JV (Gába 1972b). Tyto doklady jsou dostatečně průkazné k rekonstrukci postupu ledovce ve stejném směru, ale omezují se jen na okolí lokality a nelze je zobecňovat pro celou studovanou oblast. Některé jiné geomorfologické doklady tento směr nepotvrzují. Orientace drumlinu Písečníku naznačuje na Javornicku směr postupu ledovce na JZ (Hanáček et al. 2013b). V oblasti Žulovské pahorkatiny měl ledovec sledovat údolí Vidnávky a postupovat tedy od S $\mathrm{k} \mathrm{J}$, s odchylkami v závislosti na reliéfu krajiny (Vídeňský et al. 2007). Terénně podmíněnou změnu směru šíření ledovce potvrzují i analýzy orientací protáhlých klastů v tillech na sv. úpatí Biskupské kupy na Osoblažsku (Hanáček - Nývlt 2009) i rekonstrukce ze Šluknovské pahorkatiny (Nývlt 2001).

Rozdíly ve složení štěrkového materiálu ledovcových sedimentů lze v souvislosti s postupem ledovce vysvětlit $\mathrm{i}$ jinak. Ještě před vlastním zaledněním docházelo $\mathrm{v}$ horských oblastech vlivem glaciálního klimatu k intenzivnímu mrazovému rozpadu výchozů. Vznikalo obrovské množství detritu, který byl ve studované oblasti koluviálně, aluviálně a fluviálně transportován ze svahů Rychlebských hor a Zlatohorské vrchoviny severovýchodním a severním směrem a uložen na plochém předpolí horstev. Vzhledem $\mathrm{k}$ litologii pohoří musely být koluviální, aluviální a fluviální sedimenty v předpolí severozápadní části hlavního hřebene Rychlebských hor značně bohaté na klasty gierałtowské ortoruly, v předpolí střední a jihovýchodní části téhož hřebene pak na amfibolity. V předpolí Sokolského hřbetu a Zlatohorské vrchoviny musely tyto sedimenty velmi hojně obsahovat živcový „pórovitý“ a muskovitický kvarcit. Materiál z hlavního hřebene Rychleb byl pak dále částečně fluviálně transportován zhruba severovýchodním až východním směrem, souhlasně s depresí Nysy Kłodzke, takže byla jeho část zanesena až do předpolí Sokolského hřbetu a Zlatohorské vrchoviny. Pevninský ledovec postupující do studované oblasti generelně od $\mathrm{S}$ a nikoliv od SZ všechny tyto uloženiny erodoval a jejich materiál transportoval zpět k J, na úpatí a úbočí Rychlebských hor a Zlatohorské vrchoviny. Deprese mezi Sokolským hřbetem a Zlatohorskou vrchovinou (údolí Bělé) mohla být zaledňována současně s glaciací Vidnavské nížiny a Žulovské pahorkatiny (obr. 2). Na polském území sz. od Javornického výběžku je ve vlastní depresi Odry směr pohybu ledovce předpokládán také od SZ na JV, ale v prostoru mezi Odrou a Sudetským pohořím jsou rekonstruovány směry na J, JZ, JV (Badura et al. 1998). Ledovcová redepozice klastů provenienčně sudetských hornin ze sekundárních výskytů v neogenních a preglaciálních kvartérních sedimentech severního předpolí horstva je doložena i z Opavska a Hlučínska (Kodymová 1964). K rozsáhlému aluviálnímu a fluviálnímu transportu materiálu $\mathrm{z}$ hlavního hřebene Rychlebských hor a Zlatohorské vrchoviny do jejich severovýchodního a severního předpolí docházelo i během následujících glaciálů, kdy už pevninský ledovec do studované oblasti nezasáhl (Cháb et al. 2004; Pecina et al. 2005). Klasty granitoidů žulovského masivu, hojné $\mathrm{v}$ Kolnovicích a Písečné, mohl ledovec získávat rovněž z preglaciálních kvartérních sedimentů, prrípadně přímo $\mathrm{z}$ výchozů $\mathrm{v}$ přilehlém Polsku, severně od obou lokalit, protože zde žulovský masiv vystupuje k povrchu. Nízký podíl těchto klastů ve Staré kaolínové jámě a na Polském kopci lze vysvětlit pozicí těchto lokalit nad kaolinizovanou částí žulovského masivu, ze které nevznikal pevný detrit. $\mathrm{V}$ případě Stachlovic produkoval žulovský masiv převážně velmi hrubý detrit (až dm velké angulární klasty), vázaný navíc jen na polohy glacitektonitů.

Provenienčně místní štěrkový materiál ledovcových uloženin Písečníku, Stachlovic, Staré kaolínové jámy, Polského kopce a Kolnovic bude $\mathrm{z}$ největší části pocházet z preglaciálních aluviálních a fluviálních sedimentů, čemuž nasvědčuje už jejich poloha v plochém reliéfu, $v$ místech, kde se aluviální a fluviální akumulace tvořily i během mladších glaciálů (Cháb et al. 2004; Pecina et al. 2005). Tuto interpretaci podporují i tvarové analýzy klastů, které pro Písečník ukazují téměř vyrovnané podíly suboválných a subangulárních tvarů (stupnice podle Powerse 1953), pro Kolnovice pak převahu suboválného stupně zaoblení. U lokalit Javorná a Písečná lze vzhledem $\mathrm{k}$ jejich pozici předpokládat významnější roli preglaciálních koluvií a eventuálně výchozů jako zdrojů materiálu ledovcových sedimentů. V Písečné převládá u klastů nejhojnější komponenty (živcového „pórovitého“ kvarcitu) subangulární zaoblení (Gába 1981a) a v Javorné spadá 80\% klastů nejhojnější složky (muskovitického kvarcitu) do kategorií velmi angulární až subangulární (Hanáček 2011). Právě pro koluvia je ostrohrannost klastů typická (Růžičková et al. 2003). V př́ípadě Kolnovic, Písečné a Javorné ukazují na redepozici většiny materiálu ze starších sedimentů i nápadně nízké podíly klastů amfibolitu na těchto lokalitách ( 1-2,5\%). Amfibolit je přitom jednou $\mathrm{z}$ hlavních hornin bělského údolí i okolních svahů Sokolského hřbetu a Zlatohorské vrchoviny. V sedimentech uvedených lokalit se ale významně uplatňují živcový „pórovitý“ a muskovitický 
kvarcit, budující severní části těchto hor, kde se amfibolitová tělesa tolik nevyskytují. Právě severní části Sokolského hřbetu a Zlatohorské vrchoviny musely být hlavními zdroji materiálu pro preglaciální koluviální, aluviální a fluviální sedimenty, které progradovaly do později zaledněného předpolí těchto pohoří. Původ části materiálu v preglaciálních sedimentech Bělé naznačuje akcesorický výskyt klastů muskovitického pegmatitu a granitu v Kolnovicích a Javorné, jehož primární původ lze vztáhnout k drobným tělesům vystupujícím právě v údolí Bělé.

Xylitové klasty skorošických tillů ledovec získal erozí výchozů v oblasti Uhelné, protože tato hornina se na stavbě hlavního hřebene Rychlebských hor nepodílí, ale vyskytuje se v miocenní pánvi na jejich dnešním úpatí (Gába 1972b). Xylit tedy dokazuje, že v okolí Skorošic postupoval ledovec od SZ na JV.

\section{Rozdíly v provenienci a polymiktnosti štěrkového materiálu ledovcových sedimentů}

Významné disproporce existují v podílech klastů vzdálené (nordické a polské) provenience. Průměrně vyšší zastoupení těchto hornin v ledovcových sedimentech uložených $\mathrm{v}$ předpolí hlavního hřebene Rychleb oproti údolí Bělé bylo vysvětlováno rolí Sokolského hřbetu jako překážky v severozápadně-jihovýchodním postupu ledovce i pozicí většiny lokalit v údolí Bělé na periferii zalednění ve vyšších nadmořských výškách (Gába 1974). Velmi nízkými podíly klastů vzdáleného původu se vyznačují lokality Písečná, Javorná a subglaciální sekvence na Písečníku, pro něž je zároveň charakteristická malá polymiktnost s dominancí určité složky vysloveně místního materiálu. Nízké podíly nordických a polských klastů se objevují i ve svrchní části glacifluviální akumulace v Kolnovicích. $\mathrm{Na}$ druhou stranu jsou některé sedimenty na nordické a polské klasty mnohem bohatší (Stará kaolínová jáma, Polský kopec a spodní ćást akumulace v Kolnovicích). Pro tyto sedimenty je zároveň typická vysoká polymiktnost bez převahy některé $\mathrm{z}$ komponent. $\mathrm{K}$ těmto lokalitám lze přičíst i supraglaciální sedimenty na Písečníku, které sice neobsahují tolik provenienčně vzdálených klastů, ale jejich podíl výrazně narůstá oproti podložním subglaciálním sedimentům stejné lokality $(\mathrm{z} \sim 2,5$ na $12 \%)$. Nízce polymiktní a na nordické a polské klasty chudé sedimenty vznikly v místech, kde i zdrojové preglaciální uloženiny musely být vzhledem k litologii snosových oblastí petrograficky monotónní. Zároveň na některých z těchto míst došlo před zásahem ledovce $\mathrm{k}$ morfologicky podmíněné značné akumulaci tohoto horninově jednotvárného materiálu (preglaciální koluvia a aluvia lemující Sokolský hřbet a sedlo mezi Bílým kamenem a Strážiskem u Javorné). Velmi polymiktní a na nordické a polské klasty bohaté sedimenty vznikly v pozdější fázi odtávání ledovce, kdy se do sedimentárního systému dostával materiál z celého ledovcového tělesa a nikoliv jen $z$ báze nebo od čela ledovce. Podobná závislost složení klastů na dodávání materiálu z englaciální pozice byla zjištěna i v severních Čechách (Nývlt - Hoare 2000). Lokality s těmito sedimenty leží dále od horského úpatí, kde před zaledněním docházelo $\mathrm{k}$ míchání materiálů $\mathrm{z}$ různých aluviálních kuželů a řek, směrujících z pohoří, zatímco blíže úpatí horstev byly tyto sedimenty petrograficky mnohem monotónnější. Tuto představu podporuje petrografické složení sedimentů na Vidnavsku (Stará kaolínová jáma, Polský kopec, Stachlovice), kde narůstají podíly amfibolitu, ale zároveň zůstávají zachovány vysoké podíly gierałtowské ortoruly. Vidnavsko před zaledněním představovalo oblast směšování materiálu přinášeného ze sz. části hlavního hřebene Rychleb s materiálem přinášeným $z$ centrální a jihovýchodní části hřebene. Nízký podíl provenienčně vzdálených klastů na lokalitě Stachlovice, sousedící s lokalitami Stará kaolínová jáma a Polský kopec, je zapříčiněn odlišnou pozicí těchto lokalit $\mathrm{v}$ rámci ledovcového systému. Ve Stachlovicích se jedná o subglaciální uloženiny s materiálem derivovaným nejspíš ze štěrků preglaciální Vidnávky, jejíž deprese lokalitu ze severu ohraničuje. Dokladem je nezvykle vysoký podíl amfibolitových klastů ve Stachlovicích, které jsou dominantní složkou i mladších sedimentů uložených v údolí Vidnávky (Pecina et al. 2005). Stachlovice jsou tedy geneticky př́ibuzné subglaciálním sedimentům na Písečníku. Naproti tomu představují Stará kaolínová jáma a Polský kopec glacifluviální uloženiny výplavové plošiny, materiálově dotované $z$ různých částí ledovce. Těmto dvěma lokalitám se zase geneticky podobají supraglaciální sedimenty na Písečníku, které vznikly vertikálním odtáváním ledovce, takže získávaly klasty i z vyšších částí ledovcového tělesa (z englaciálního prostředí). V př́padě Kolnovic může být vertikální proměnlivost petrograficko-provenienčního složení zapříčiněna i přínosem materiálu z různých částí dlouhého ledovcového čela během agradace sedimentů této proglaciální výplavové plošiny, jelikož plošina se vyvíjela až v době, kdy ledovec ustoupil $\mathrm{z}$ bezprostředního úpatí hor a v plochém reliéfu mohl mít dlouhý a západo-východně protáhlý okraj (Hanáček 2012). Rapidní pokles podílu klastů vzdáleného původu v mocné štěrkové vrstvě v Kolnovicích (vzorky G1f a G1g) je pravděpodobně také výsledkem vysokoenergetických podmínek trasportu během její akumulace, protože materiál je zjevně nabohacen o mechanicky odolné horniny (křemen a kvarcity). Významně se uplatnila i průměrně větší hrubozrnnost tohoto sedimentu, jelikož nordické a polské klasty jsou hojnější v jemnozrnnějších uloženinách.

\section{Provenience křemene}

Dřívější výzkumy ukazují na převážně místní původ křemenných klastů v ledovcových sedimentech Jesenicka, ačkoliv část křemene může být polské až nordické provenience (Gába 1974, 1976). Většina indicií nasvědčuje místnímu původu převážné části křemenných klastů. Na každé z lokalit se hojně vyskytují (někdy i převažují) klasty tvořené nejen křemenem, ale i zbytky okolních hornin a jejich minerály, podle nichž lze dovodit primární zdroje křemene. Na Písečníku se jedná o načervenalé živce, slídy, granát a kvarcit. Načervenalé živce lze vztáhnout ke gierałtowské ortorule. V Kolnovicích jsou běžnou součástí křemenných klastů bílé živce a slídy, ojediněle andaluzit, amfibol, sillimanit a granát. Bílé živce a slídy indikují souvislost křemenných klastů s místními pegmatity (v Kolnovicích tvoří pegmatity až 5,5\% klastů) a živcovým „porovitým“ 
kvarcitem, andaluzit se vyskytuje ve svorech údolí Bělé. Sillimanit a granát jsou běžnými minerály biotitické až sillimanit-biotitické pararuly, která tvoří skalní podloží mezi Kolnovicemi a Písečnou a zároveň obsahuje křemenné čočky. V Javorné tvoří ve frakci 16-64 mm asi 6-11\% klastů křemen s polohami slíd a se zbytky fylitu, svoru a vzácněji amfibolitu. Zhruba 50 \% klastů tohoto křemene vykazuje angulární až velmi angulární stupeň zaoblení, dalších $\sim 40 \%$ klastů je subangulárních. Podle těchto znaků pocházejí v Javorné křemenné klasty se zbytky horniny $\mathrm{z}$ čoček v metamorfitech okolní vrbenské skupiny.

$\mathrm{V}$ sedimentech u Javorné byl zjištěn tento vztah mezi zaoblením křemene a podíly klastů vzdáleného a místního původu. S růstem podílů provenienčně vzdálených hornin narůstá i podíl oválného a dokonale oválného křemene a naopak, angulární a velmi angulární křemen je nejčastější v sedimentech s vysokými podíly místních hornin (Hanáček 2011). V podstatě stejný trend byl pozorován i na Písečníku. Oválný a dokonale oválný křemen může pocházet z fluviálních sedimentů Polska nebo až z nordické oblasti.

Celkově popsané výsledky potvrzují původní názory na převážně místní původ křemene $\mathrm{v}$ ledovcových sedimentech Jesenicka.

\section{Závěry}

Podle skladby místních klastů ledovcových sedimentů lze postup ledovce v severním předpolí Rychlebských hor a Zlatohorské vrchoviny rekonstruovat generelně ve směru S-J s lokálními terénně podmíněnými odchylkami. Zdroji místního materiálu ledovcových uloženin byly hlavně koluviální, aluviální a fluviální sedimenty, vzniklé v glaciálních klimatických podmínkách a progradující z pohoří do plochého předpolí, které bylo následně pokryto pevninským ledovcem.
Ledovcové sedimenty s nízkými podíly nordických a polských klastů se zároveň vyznačují celkově slabou polymiktností. Uložily se blíže $\mathrm{k}$ pohoří, kde zdrojové preglaciální sedimenty byly petrograficky rovněž jednotvárné a kde místy došlo $\mathrm{k}$ morfologicky podmíněné akumulaci těchto zdrojových sedimentů. Naproti tomu vznikaly ledovcové sedimenty s vysokými podíly nordických a polských klastů a celkově vysokou polymiktností dále od pohoří, kde i zdrojové sedimenty byly kvưli předchozímu smíchání materiálu v preglaciálním období mnohem polymiktnější. Zároveň se během pokročilejší fáze deglaciace dostával do sedimentárního systému ve větší míře materiál ze všech částí ledovce.

Výzkum potvrdil dřivější názory na převážně místní původ křemenných klastů.

\section{Poděkování}

Vznik článku byl podpořen projektem OPVK 2.4 PasGeo Partnerská sít pro spolupráci a aplikace v geoenvironmentálních a geotechnických oborech, reg. č. CZ.1.07/2.4.00/31.0019. Velmi děkuji Martinu Palečkovi z České geologické služby za spolupráci na tvorbè generalizované geologické mapy studované oblasti, která se stala základem pro zjednodušenou mapku $v$ tomto př́spěvku. Vlastivědnému muzeu $v$ Šumperku a jmenovitě jeho pracovnici paní Evě Petrášové děkuji za ochotné zpř́stupnèní rukopisu práce Z. Gáby „Dokumentace a výzkum těžené lokality Písečná“. Danielu Nývltovi z Geografického ústavu Př́rodovědecké fakulty MU děkuji za přeložení anglických částí textu. Recenzentu Danielu Šimíčkovi z Katedry geologie Přírodovědecké fakulty UP v Olomouci jsem zavázán za připomínky $k$ rukopisu tohoto článku.

\section{Literatura}

Badura, J. - Krzyszkowski, D. - Przybylski, B. (1998): Stratygrafia glin lodowcowych, liczba zlodowaceń i kierunki transportu lodowcowego w południowej części przedgórza sudeckiego (okolice Ząbkowic), Polska południowo-zachodnia. - Biuletyn Państwowego instytutu geologicznego, 385, 29-48.

Černá, B. - Nývlt, D. - Engel, Z. (2012): A buried glaciofluvial channel in the Anděl Col, Northern Bohemia: new evidence for the Middle Pleistocene ice sheets extend in Western Sudetes. - Geografie, 117, 127-151.

Gába, Z. (1972a): Nejzazší výskyty uloženin kontinentálního zalednění na Jesenicku. - Časopis Slezského muzea (A), 21, 135-139.

Gába, Z. (1972b): Souvková hlína ze Skorošic a směr pohybu pevninského ledovce. - Zprávy Vlastivědného ústavu v Olomouci, $155,23-28$.

Gába, Z. (1974): Valounové analýzy ledovcových uloženin na Jesenicku. - Časopis Slezského Muzea Opava (A), $23,49-56$.

Gába, Z. (1976): Valounové analýzy vodně ledovcových uloženin moravskoslezské oblasti. - Časopis Slezského muzea (A), $25,57-62$. 
Gába, Z. (1977): Petrografie ledovcových souvků jesenické oblasti ve Slezsku. - Práce odboru př́rodních věd Vlastivědného ústavu v Olomouci, 30, $39 \mathrm{~s}$.

Gába, Z. (1981a): Dokumentace a výzkum těžené lokality Písečná - MS, Vlastivědné muzeum v Šumperku, $91 \mathrm{~s}$.

Gába, Z. (1981b): Uloženiny kontinentálního ledovce u Písečné na severní Moravě. - Časopis Slezského Muzea Opava (A), 30, 3, 241-253.

Gába, Z. (1992): Profil ledovcovými uloženinami u Vidnavy ve Slezsku. - Časopis Slezského muzea (A), 41, 167-172.

Gába, Z. - Pek, I. (1999): Ledovcové souvky moravskoslezské oblasti. - Okresní vlastivědné muzeum v Šumperku.

Gába, Z. - Wójcik, J. (1990): Sudetské porfyry jako vůdčí souvky v ledovcových uloženinách Polska a ČSFR. - Časopis Slezského Muzea (A), 39, 59-65.

Hanáček, M. (2008): Valounové analýzy glacifluviálních sedimentů na lokalitě Stará kaolínová jáma u Vidnavy na Jesenicku. Časopis Slezského zemského muzea (A), 57, 222-236.

Hanáček, M. (2011): Sedimenty terminoglaciálního kuželu v údolí Javorné na Zlatohorsku. - Acta Musei Moraviae, Scientiae geologicae, 96, 61-86.

Hanáček, M. (2012): Glacifluviální výplavová plošina u Kolnovic a její srovnání s terminoglaciálními kužely mezi Sokolským hřbetem a Zlatohorskou vrchovinou u Jeseníku. - Geologické výzkumy na Moravě a ve Slezsku 19, 17-25.

Hanáček, M. - Nývlt, D. (2009): Subglaciální štěrkovité tilly u Jindřichova na Osoblažsku. - Časopis Slezského zemského muzea (A), 58, 193-214.

Hanáček, M. - Nývlt, D. - Nehyba, S. (2013a): Depositional settings of the Pleistocene continental glaciation sediments in the foothills of Rychleby Mountains and Zlate Hory Highlands, Sudetes Mts., Czechia. - In: XX Konferencja Stratygrafia plejstocenu Polski Plejstocen przedpola Sudetów Środkowych Lasocin, 2.-6. 9. 2013 r., 51-55.

Hanáček, M. - Nývlt, D. - Nehyba, S. (2013b): Písečník u Javorníku - drumlin se zachovalou sukcesí subglaciálních a supraglaciálních sedimentů. - Geologické výzkumy na Moravě a ve Slezsku, 20, 22-29.

Cháb, J. - Čurda, J. - Kočandrle, J. - Manová, M. - Nývlt, D. - Pecina, V. - Skácelová, D. -Večeřa, J. - Žáček, V. (2004): Základní geologická mapa České republiky 1 : 25 000, list 14-224 Jeseník s Vysvětlivkami. - Česká geologická služba.

Kodymová, A. (1964): Petrografické složení ledovcových sedimentů na Opavsku a Hlučínsku a jeho význam pro stratigrafii. Antropozoikum, A, 2, 73-83.

Kopečný, V. - Pek, I. (1974): Petrografické složení souvkových hlin na Vidnavsku a Osoblažsku. - Acta Universitatis Palackianae Olomucensis, Facultas Rerum Naturalium, 46, 25-50.

Nývlt, D. (2001): Main advance directions and maximum extent of Elsterian ice sheet in the eastern part of the Šluknov Hilly Land, Northern Bohemia, Czechia. - Slovak Geological Magazine, 7, 231-235.

Nývlt, D. - Engel, Z. - Tyráček, J. (2011): Pleistocene glaciations of Czechia. - In: Ehlers, J., Gibbard, P. L., Hughes, P. D. (eds.): Quaternary Glaciations - Extent and Chronology Part IV - a closer look. Developments in Quaternary Science, Elsevier, $37-46$.

Nývlt, D. - Hoare, P. G. (2000): Valounové analýzy glacifluviálních sedimentů severních Čech. - Věstník Českého geologického ústavu, 75, 121-126.

Pecina, V. - Čurda, J. - Hanáček, M. - Kočandrle, J. - Nývlt, D. - Opletal, M. - Skácelová, D. - Skácelová, Z. - Večeřa, J. - Žáček, V. (2005): Základní geologická mapa České republiky 1: 25 000, list 14-221 Žulová s Vysvětlivkami. - MS, Česká geologická služba.

Pouba, Z. (1996): Geologická mapa ČR. Mapa předčtvrtohorních útvarů $1: 200$ 000, list Jeseník. - Český geologický ústav.

Pouba, Z. - Dvořák, J. - Kužvart, M. - Mísař, Z. - Musilová, L. - Prosová, M. - Röhich, P., - Skácel, J. - Unzeitig, M. (1962): Vysvětlivky k přehledné geologické mapě ČSSR $1: 200$ 000, list M-33-XVIII Jeseník. - Ústřední ústav geologický.

Powers, M. C. (1953): A new roundness scale for sedimentary particles. - Journal of Sedimentary Petrology, 23, 117-119.

Prosová, M. (1981): Oscilační zóna kontinentálního ledovce. Jesenická oblast. - Acta Universitatis Carolinae, Geologica, 3, $265-294$.

Růžičková, E. - Růžička, M. - Zeman, A. - Kadlec, J. (2003): Kvartérní klastické sedimenty České republiky. Struktury a textury hlavních genetických typů. - Česká geologická služba, $68 \mathrm{~s}$.

Sawicki, L. (1995): Mapa geologiczna regionu Dolnośląskiego z przyległymi obszarami Czech i Niemiec (bez utworów czwartorzędowych) $1: 100$ 000. - Państwowy instytut geologiczny.

Sedláček, J. (2008): Studium sedimentů kontinentálního zalednění ve východní části Opavska. - MS, diplomová práce, Přírodovědecká fakulta Masarykovy univerzity, $75 \mathrm{~s}$. Brno.

Sikorová, J. - Víšek, J. - Nývlt, D. (2006): Texture and petrography of glacial deposits in the northern foothill of the Hrubý Jeseník and Rychlebské Mts., Czechia. - Geological Quarterly, 50, 3, 345-352.

Skácelová, D. (1993): Geologická mapa ČR 1 : 50 000. List 14-21 Travná. - Český geologický ústav.

Skácelová, D. (1994): Geologická mapa ČR 1 : 50 000. List 04-43 Bílý Potok. - Český geologický ústav.

Svoboda, J. (1990): Geologická mapa ČSSR. Mapa předčtvrtohorních útvarů $1: 200$ 000. List Náchod. - Ústřední ústav geologický.

Svoboda, J. - Chaloupský, J. - Bernard, J. - Dornič, J. - Kalášek, J. - Klein, V. - Malkovský, M. - Mísař, Z. - Pacovská, E. - Pauk, F. - Řezáč, B. - Skácel, J. - Soukup, J. - Tásler, R. - Vodička, J. - Zrůstek, V. (1961): Vysvětlivky k přehledné geologické mapě ČSSR $1: 200$ 000, M-33-XVII Náchod. - Ústřední ústav geologický.

Šimíček, D. (2009) : Studium sedimentů kontinentálního zalednění v Bohušovské pískovně na Osoblažsku. - Geologické výzkumy na Moravě a ve Slezsku, 16, 42-47.

Štor, T. (2009): Architekturní a litofaciální analýza glacifluviálních sedimentů výplně Václavického subglaciálního koryta na lokalitě Grabštejn. - MS, diplomová práce PřF UK, 66 s. Praha.

Vídeňský, A. - Nývlt, D. - Štěpančíková, P. (2007): Příspěvek k otázce vzniku granitoidních elevací v západní části Černovodské pahorkatiny, žulovský batolit. - Geologické výzkumy na Moravě a ve Slezsku, 14, 35-39.

Žáček, V. (1995): Geologická mapa ČR 1: 50 000. List 14-22 Jeseník. - Český geologický ústav.

Žáček, V. - Čurda, J. - Kočandrle, J. - Nekovař́ík, Č. - Nývlt, D. - Pecina, V. - Skácelová, D. - Skácelová, Z. - Večeřa, J. (2004): Základní geologická mapa České republiky 1:25 000, list 14-222 Vidnava s Vysvětlivkami. - Česká geologická služba. 